\title{
Cleavable olivine in serpentinite mylonites from the Oeyama ophiolite
}

\author{
Toshio NOZAKA and Yuki ITO \\ Department of Earth Sciences, Okayama University, Okayama 700-8530, Japan
}

\begin{abstract}
Olivine that has well-developed parting similar to cleavage, i.e., so-called "cleavable olivine", occurs in peridotites at many localities of orogenic belts and the seafloor. Some conflicting hypotheses for the genesis of the parting have been proposed but not yet fully proved or disproved. We present new data of structural, petrological and mineralogical analyses of cleavable olivine and host ultramafic rocks in the Oeyama ophiolitic complexes, SW Japan. The following are our key findings to understand the genesis of cleavable olivine. 1) Cleavable olivine is distributed in the ultramafic complexes regardless of metamorphic grade of contact aureoles. 2) Cleavable olivine from contact aureoles has variable chemical compositions by the effect of thermal metamorphism. 3) Cleavable olivine commonly occurs in or near serpentinite mylonites. 4) Antigorite blades commonly occur along the parting planes of olivine, and the parting planes along with antigorite blades are locally bent to the direction of foliation. 5) Poles of the parting planes of olivine tend to be distributed around a plane vertical to the foliation of host serpentinite mylonite. From these facts we conclude that cleavable olivine was produced during a sequence of localized plastic deformation and alteration of peridotites at temperatures around $600{ }^{\circ} \mathrm{C}$ or lower. The parting is likely to have derived from dislocation arrangement by recovery processes after plastic deformation of hydrous peridotites and have been brought into prominence during syntectonic serpentinization. The preferred orientation of the parting planes suggests that cleavable olivine is a potential indicator of regional tectonics of the upper mantle at supra-subduction zones.
\end{abstract}

Keywords: Cleavable olivine, Parting, Deformation, Serpentinite, Peridotite, Mylonite, Oeyama ophiolite

\section{INTRODUCTION}

So-called "cleavable olivine" (Kuroda and Shimoda, $1967)$ is the olivine that apparently has perfect cleavage faces parallel to (010), (100) and/or (001). Single-crystal $\mathrm{X}$-ray diffraction analyses and optical observations of heated crystals by Aikawa (1981) have revealed that the "cleavage faces" are actually parting planes with high dislocation density. Because many workers have been used the terms "cleavable olivine" and "cleavage" for the descriptions of this type of olivine, we will use "cleavable olivine" as well for convenience; to avoid confusion, however, we will not use "cleavage" for the parting in this paper.

Since the first report from the Klamath Mountains, United States by Hawkes (1946), cleavable olivine has been found in peridotitic rocks from many localities of orogenic belts. With its prominent appearance, cleavable olivine has been interested by many researchers, and some conflicting hypotheses for its genesis have been pro-

doi:10.2465/jmps.100408

T. Nozaka,nozaka@cc.okayama-u.ac.jp Corresponding author posed. Kuroda and Shimoda (1967) and Kuroda (1969) suggested that the cleavable olivine was caused by highpressure crystallization and resulting unusual crystal structure, but this idea have been disproved by advanced X-ray analyses of Aikawa (1981) and Aikawa and Tokonami (1987). Others ascribed the cleavable olivine to deformation related to tectonic movement (Velinsky and Pinus, 1969; Aikawa, 1981; Kutty et al. 1983) or annealing after thermal metamorphism (Uda, 1984). Recently, the occurrence of cleavable olivine has been reported from serpentinized peridotites collected from the seafloor (Ishii et al., 1992; Ohara and Ishii, 1998; Niida et al., 2001; Murata et al., 2009). The lack of evidence for prograde metamorphism in these peridotites and for existence of heat source at the seafloor is inconsistent with the newest hypothesis that relates the formation of cleavable olivine to thermal metamorphism. In addition, observations of serpentinite mylonites from the Happo ultramafic complex (Nozaka, 2005) suggested a relationship between cleavable olivine and deformation.

The Oeyama ultramafic complex is the locality where cleavable olivine has been most intensively studied 
and conflicting hypotheses mentioned above have been proposed. The Wakasa ultramafic complex is another locality where cleavable olivine is frequently found as well. We, therefore, selected the two ultramafic complexes of the Oeyama ophiolite for reinvestigation of cleavable olivine, and tested the hypotheses with a new set of structural, petrological and mineralogical data. The results of our studies provide evidence for a close relationship of cleavable olivine to a sequence of plastic deformation and syntectonic alteration processes.

\section{GEOLOGICAL SETTING AND GENERAL DE- SCRIPTIONS OF THE OEYAMA OPHIOLITE}

The Oeyama ophiolite in this article refers to the ultramafic complexes that are exposed from the Oeyama to Wakasa areas in close association with Renge high- $P / T$ metamorphic rocks (Fig. 1a; Ishiwatari, 1989, 1990; Nishimura, 1998). The main components of the Oeyama ophiolite are serpentinized peridotites, which include tectonic blocks or intrusions of pyroxenite, gabbro, amphibolite and jadeitite (Igi and Kuroda, 1965; Kurokawa, 1975, 1985; Kuroda et al., 1976; Uemura et al., 1979; Uda, 1984; Chihara, 1989; Yamaguchi, 1990; Tsujimori and
Liou, 2004). The gabbroic rocks and amphibolites show $\mathrm{K}$-Ar radiometric ages of 400-470 Ma (Nishimura and Shibata, 1989; Tsujimori et al., 2000).

The Oeyama ophiolite is similar to the ultramafic complexes exposed around the Tari-Misaka and Happo areas (Fig. 1a) in lithology, age of amphibolite blocks and close association with high $-P / T$ metamorphic rocks (Arai, 1980; Nishimura, 1998; Tsujimori et al. 2000; Takeuchi, 2002). The Tari-Misaka and Happo ultramafic complexes have characteristics suggestive of sub-arc mantle origin (Arai and Yurimoto, 1995; Khedr and Arai, 2010), and therefore, the Oeyama ophiolite could originate in a Paleozoic supra-subduction zone (Ishiwatari, 1989; Ishiwatari and Tsujimori, 2003). However, because there are some differences in radiometric ages and mineralogy of residual peridotites between the Oeyama ophiolite and ultramafic complexes around the Tari-Misaka area, it is possible as well that they belong to separate terranes (Ishiwatari, 1990).

The Oeyama and Wakasa ultramafic complexes are in fault contact with Paleozoic formations or Renge metamorphic rocks, and intruded by Cretaceous or Paleogene granitic rocks, and then, covered by younger sediments or volcanics (Figs. 1b and 1c; Igi and Kuroda, 1965; Uemura
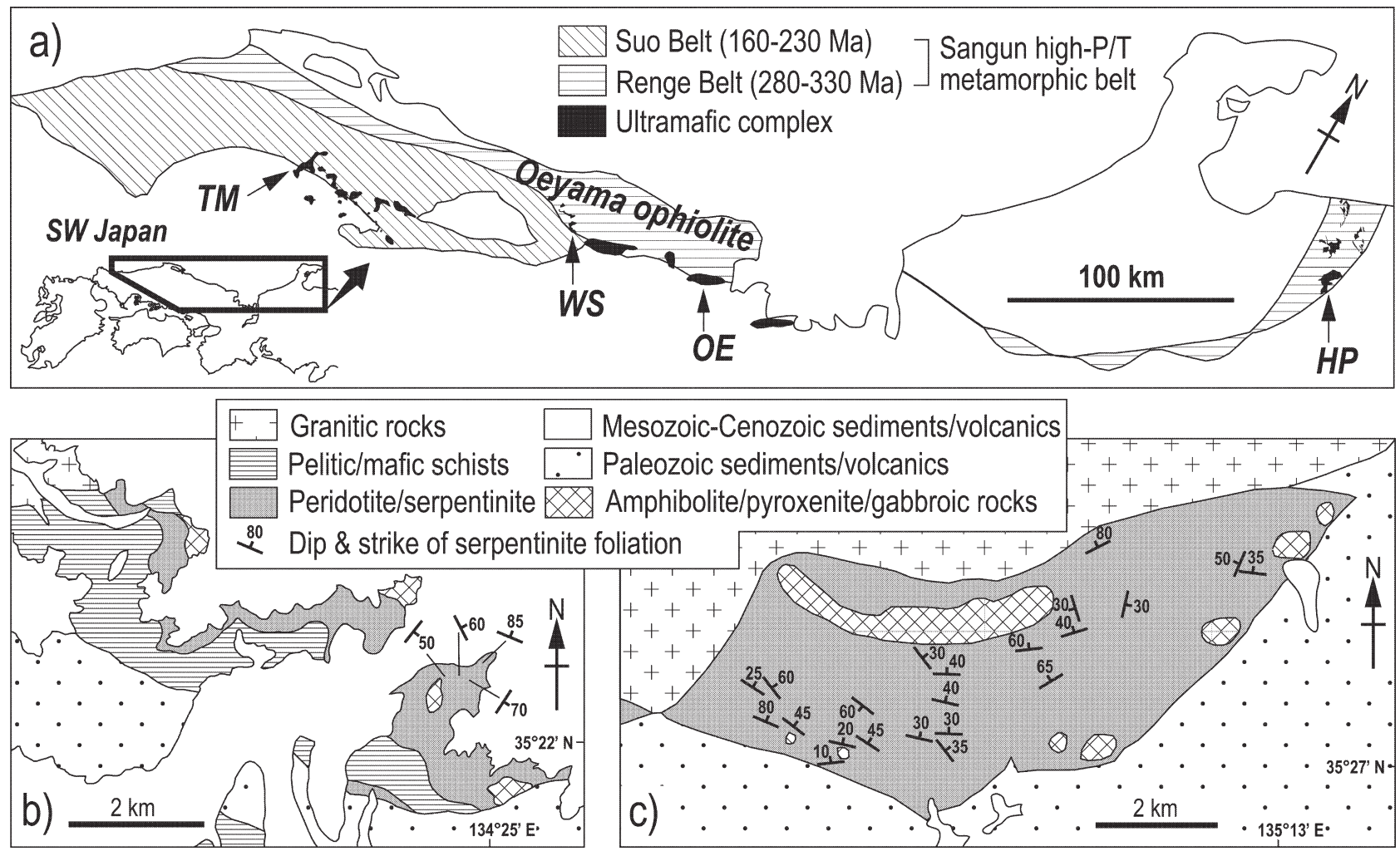

Figure 1. (a) Distribution of ultramafic complexes and the Sangun high- $P / T$ metamorphic belt in SW Japan (Ishiwatari, 1989, 1990; Nishimura, 1998; Takeuchi, 2002). Abbreviations for ultramafic complexes: OE, Oeyama; WS, Wakasa; HP, Happo; TM, Tari-Misaka. (b) Geological sketch map of the Wakasa area (Uemura et al, 1979). (c) Geological sketch map of the Oeyama area (Igi and Kuroda, 1965; Uda, 1984; Kurokawa, 1985). Representative data of dip and strike of mylonite foliation measured in this study are also shown. 
et al., 1979; Uda, 1984; Kurokawa, 1985). The complexes have contact aureoles with increasing metamorphic grade toward the granitic intrusion (Fig. 2a). Details of the thermal metamorphism will be described in the next section.

Lithology of original peridotite looks to be variable between the complexes of the Oeyama ophiolite and even within a complex. For example, estimate of modal proportion of pyroxene in peridotites from the Oeyama complex has been different between previous studies (Uda, 1984; Kurokawa, 1985). Incidentally, we point out that modal compositions of original rocks must be cautiously estimated in the case of serpentinized peridotites that contain cleavable olivine, because cleavable olivine is very similar in appearance to orthopyroxene, and serpentine pseudomorphs after cleavable olivine may be misidentified as those after orthopyroxene (i.e., bastite) even under the microscope. Rocks inspected in this study look to be dominantly dunite with subordinate amounts of harzburgite and lherzolite. Chromite with an equant or oval (elongated by deformation) shape is common in the dunites, whereas $\mathrm{Cr}$-spinel with a vermicular shape occurs in harzburgites and lherzolites, showing consistency with the
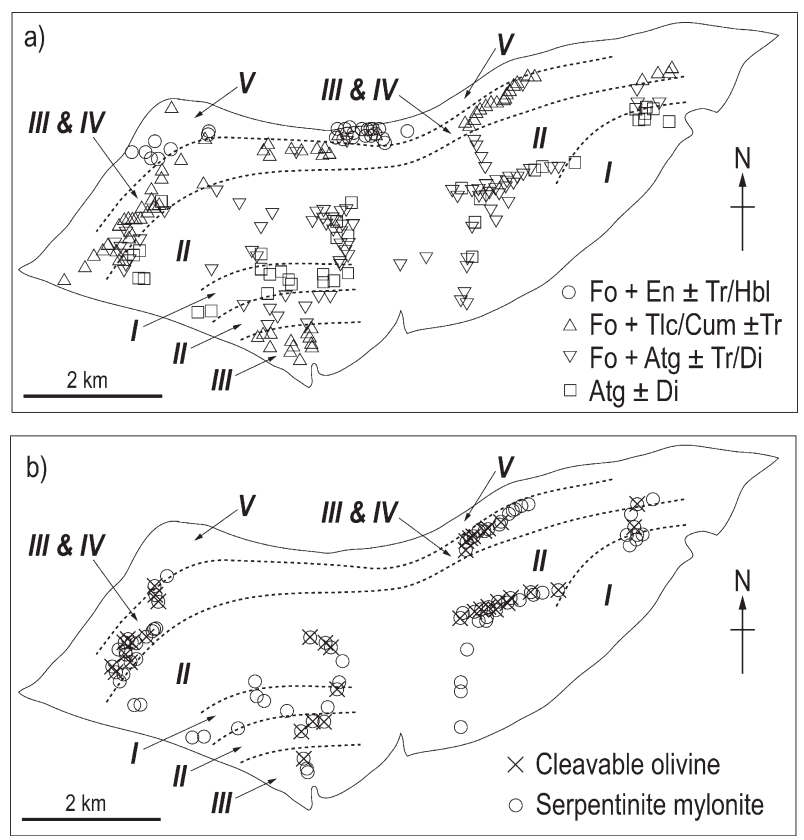

Figure 2. (a) Metamorphic zonal map showing distribution of thermally metamorphic mineral assemblages. Forsterite in Zone II includes the reticulate olivine (Fig. 3c; see text for details). Plots of the localities of mineral assemblages include those of Uda (1984). Abbreviations for minerals: Atg, antigorite; Cum, cummingtonite; Di, diopside; En, enstatite; Fo, forsterite; Hbl, hornblende; Tlc, talc; Tr, tremolite. (b) Distribution of cleavable olivine (including its serpentine pseudomorphs) and serpentinite mylonites (including thermally metamorphosed rocks with visible foliation) in the Oeyama complex. Plots of the localities in this figure are only based on our study. general tendency of a relationship between spinel morphology and lithology (Arai, 1980; Matsumoto and Arai, 2001).

Serpentinite mylonites with strong foliation, which is microscopically characterized by lepidoblastic antigorite with olivine porphyroclasts and neoblasts, occur throughout the Oeyama and Wakasa complexes (Fig. 2b). The serpentinite mylonites are similar in appearance to those from the Josephine ophiolite and the Happo ultramafic complex (Norrell et al., 1989; Nozaka, 2005). Massive serpentinites or peridotites without foliation occur as well, but those in the highest-grade metamorphic zone could be serpentinite mylonites of which foliation disappeared by thermal metamorphism. The strikes of foliation show a general trend of NW-SE and NE-SW in the Oeyama and Wakasa complex, respectively, with local perturbation by faulting or folding (Figs. 1b and 1c).

\section{ANALYTICAL PROCEDURES}

Oriented samples and thin sections cut perpendicularly to foliation were prepared for structural analyses of serpentinite mylonites. Samples that contain many grains of cleavable olivine were selected for measurement of the attitude of parting planes on a five-axes universal stage. We did not determine lineation, though essential for structural analysis, because of the scarcity or obscurity of lineation in the inspected samples, in particular the rocks containing many grains of cleavable olivine.

The chemical compositions of the minerals were analyzed using an electron probe micro-analyzer with three spectrometers (JEOL JXA-733) at Advanced Science Research Center of Okayama University, with an accelerating voltage of $15 \mathrm{kV}$, a sample current of $10-20 \mathrm{nA}$, and a focused beam of 1-2 $\mu \mathrm{m}$ in diameter. Standards used were natural or synthetic oxides and silicates. The matrix corrections employed followed the procedures of Bence and Albee (1968), using the alpha factors of Nakamura and Kushiro (1970). Representative analyses are listed in Tables 1 and 2.

Micro-Raman spectroscopic analyses of serpentine minerals were carried out at Department of Material Chemistry of Okayama University with a Raman spectroscope system (Jobin Yvon T64000) using $514.5 \mathrm{~nm}$ laser excitation with $200 \mathrm{~mW}$ incident power, a $100 \times$ microscope objective lens, and a diffraction grating with groove density of 1800 1/mm. Raman shift spectra of polished thin-sections were acquired for 30 seconds and integrated five times. Baselines of the spectra were corrected using GRAMS $^{\mathrm{TM}}$ software. 
Table 1. Representative microprobe analyses of olivine

\begin{tabular}{|c|c|c|c|c|c|c|c|}
\hline Metamorphic zone & I & I & II & II & I & II & II \\
\hline Sample & WS0517 & WS0517 & WS0615 & WS0615 & OE0815 & OE0841 & OE0841 \\
\hline Type & Cleavable & Neoblastic & Cleavable & Neoblastic & Cleavable & Cleavable & Reticulate \\
\hline $\mathrm{SiO}_{2}(\mathrm{wt} \%)$ & 39.31 & 38.98 & 40.43 & 40.07 & 40.04 & 40.19 & 40.88 \\
\hline $\mathrm{FeO}^{*}$ & 9.25 & 8.46 & 10.20 & 10.63 & 9.70 & 10.31 & 3.07 \\
\hline $\mathrm{MnO}$ & 0.39 & 0.39 & 0.24 & 0.27 & 0.27 & 0.35 & 0.54 \\
\hline $\mathrm{NiO}$ & 0.34 & 0.25 & 0.40 & 0.33 & 0.44 & 0.38 & 0.23 \\
\hline $\mathrm{MgO}$ & 51.04 & 50.98 & 49.06 & 48.83 & 48.78 & 49.62 & 55.82 \\
\hline $\mathrm{CaO}$ & 0.02 & 0.01 & 0.03 & 0.02 & 0.00 & 0.00 & 0.03 \\
\hline Total & 100.35 & 99.07 & 100.36 & 100.15 & 99.23 & 100.85 & 100.57 \\
\hline $\mathrm{O}$ & 4.000 & 4.000 & 4.000 & 4.000 & 4.000 & 4.000 & 4.000 \\
\hline $\mathrm{Si}$ & 0.964 & 0.965 & 0.992 & 0.987 & 0.992 & 0.983 & 0.972 \\
\hline $\mathrm{Fe}$ & 0.190 & 0.175 & 0.209 & 0.219 & 0.201 & 0.211 & 0.061 \\
\hline $\mathrm{Mn}$ & 0.008 & 0.008 & 0.005 & 0.006 & 0.006 & 0.007 & 0.011 \\
\hline $\mathrm{Ni}$ & 0.007 & 0.005 & 0.008 & 0.006 & 0.009 & 0.007 & 0.004 \\
\hline $\mathrm{Mg}$ & 1.866 & 1.882 & 1.794 & 1.794 & 1.801 & 1.809 & 1.979 \\
\hline $\mathrm{Ca}$ & 0.001 & 0.000 & 0.001 & 0.001 & 0.000 & 0.000 & 0.001 \\
\hline Total & 3.036 & 3.035 & 3.009 & 3.013 & 3.009 & 3.017 & 3.028 \\
\hline Fo & 90.8 & 91.5 & 89.6 & 89.1 & 90.0 & 89.6 & 97.0 \\
\hline Metamorphic zone & II & II & III & III & III & III & $\mathrm{V}$ \\
\hline Sample & OE0817 & OE0817 & OE08136 & OE08136 & OE08107 & OE08137 & OE08109 \\
\hline Type & Uncleavable & Reticulate & Cleavable & Cleavable & Granoblastic & Granoblastic & Granoblastic \\
\hline $\mathrm{SiO}_{2}(\mathrm{wt} \%)$ & 40.90 & 41.05 & 40.54 & 40.71 & 40.40 & 41.42 & 40.43 \\
\hline $\mathrm{FeO}^{*}$ & 8.85 & 6.58 & 8.74 & 4.12 & 8.55 & 3.75 & 6.92 \\
\hline $\mathrm{MnO}$ & 0.25 & 0.58 & 0.77 & 2.44 & 0.10 & 0.51 & 0.15 \\
\hline $\mathrm{NiO}$ & 0.37 & 0.05 & 0.07 & 0.00 & 0.28 & 0.04 & 0.39 \\
\hline $\mathrm{MgO}$ & 49.87 & 51.94 & 50.74 & 54.28 & 51.15 & 54.92 & 51.66 \\
\hline $\mathrm{CaO}$ & 0.00 & 0.05 & 0.02 & 0.01 & 0.01 & 0.08 & 0.02 \\
\hline Total & 100.24 & 100.25 & 100.88 & 101.56 & 100.49 & 100.72 & 99.57 \\
\hline $\mathrm{O}$ & 4.000 & 4.000 & 4.000 & 4.000 & 4.000 & 4.000 & 4.000 \\
\hline $\mathrm{Si}$ & 0.997 & 0.991 & 0.984 & 0.970 & 0.982 & 0.984 & 0.985 \\
\hline $\mathrm{Fe}$ & 0.180 & 0.133 & 0.177 & 0.084 & 0.174 & 0.074 & 0.141 \\
\hline $\mathrm{Mn}$ & 0.005 & 0.012 & 0.016 & 0.049 & 0.002 & 0.010 & 0.003 \\
\hline $\mathrm{Ni}$ & 0.007 & 0.001 & 0.001 & 0.000 & 0.006 & 0.001 & 0.008 \\
\hline $\mathrm{Mg}$ & 1.813 & 1.870 & 1.837 & 1.927 & 1.854 & 1.945 & 1.877 \\
\hline $\mathrm{Ca}$ & 0.000 & 0.001 & 0.000 & 0.000 & 0.000 & 0.002 & 0.000 \\
\hline Total & 3.002 & 3.008 & 3.015 & 3.030 & 3.018 & 3.016 & 3.014 \\
\hline Fo & 91.0 & 93.4 & 91.2 & 95.8 & 91.4 & 96.3 & 93.0 \\
\hline
\end{tabular}

* Total iron as $\mathrm{FeO}$.

OE and WS of the sample numbers indicates Oeyama and Wakasa, respectively.

\section{METAMORPHIC ZONAL MAPPING}

Because Uda (1984) has considered that the formation of cleavable olivine was related to thermal metamorphism, we examined first the effect of the metamorphism on the ultramafic complexes and consequently confirmed the overall descriptions of previous studies. Uda (1984) and Kurokawa (1985) divided the contact aureole of the Oeyama complex into four or five zones. Our metamorphic zonal map (Fig. 2a) has no difference from those of the previous studies except for minor corrections in the position of isograds and in index mineral assemblage of each zone.

According to the general scheme of thermally metamorphosed ultramafic rocks in SW Japan (Arai, 1975; Mastumoto et al., 1995; Nozaka and Shibata, 1995; Nozaka, 2003), each metamorphic zone is defined by the following mineral assemblage in the order of increasing grade: Zone I, antigorite \pm diopside; Zone II, forsterite + antigorite \pm tremolite or diopside; Zone III, forsterite + 
Table 2. Representative microprobe analyses of mafic minerals

\begin{tabular}{|c|c|c|c|c|c|c|c|}
\hline Metamorphic zone & I & II & I & II & III & II & V \\
\hline Sample & WS0517 & WS0615 & OE0815 & OE0841 & OE08107 & OE0886 & OE08109 \\
\hline Mineral & Antigorite & Antigorite & Antigorite & Antigorite & Talc & Enstatite & Enstatite \\
\hline Type & Lepidoblastic & Lepidoblastic & Ol-parting & Ol-parting & Metamorphic & Primary & Metamorphic \\
\hline $\mathrm{SiO}_{2}$ & 40.85 & 42.33 & 42.27 & 41.09 & 59.63 & 55.34 & 57.64 \\
\hline $\mathrm{TiO}_{2}$ & 0.03 & 0.03 & 0.04 & 0.00 & 0.02 & 0.03 & 0.01 \\
\hline $\mathrm{Al}_{2} \mathrm{O}_{3}$ & 2.24 & 1.06 & 1.43 & 1.34 & 1.30 & 4.11 & 0.27 \\
\hline $\mathrm{Cr}_{2} \mathrm{O}_{3}$ & 0.96 & 0.46 & 0.90 & 0.48 & 0.18 & 0.83 & 0.03 \\
\hline $\mathrm{FeO} *$ & 3.17 & 2.58 & 2.75 & 2.14 & 1.99 & 6.23 & 5.07 \\
\hline $\mathrm{MnO}$ & 0.12 & 0.11 & 0.05 & 0.08 & 0.02 & 0.13 & 0.12 \\
\hline $\mathrm{NiO}$ & 0.06 & 0.08 & 0.15 & 0.09 & 0.08 & 0.16 & 0.09 \\
\hline $\mathrm{MgO}$ & 39.97 & 40.51 & 39.88 & 41.74 & 30.37 & 33.04 & 36.33 \\
\hline $\mathrm{CaO}$ & 0.00 & 0.00 & 0.00 & 0.00 & 0.02 & 1.46 & 0.08 \\
\hline $\mathrm{Na}_{2} \mathrm{O}$ & nd & nd & nd & nd & 0.42 & 0.03 & 0.00 \\
\hline $\mathrm{K}_{2} \mathrm{O}$ & nd & nd & nd & nd & 0.03 & 0.01 & 0.02 \\
\hline Total & 87.40 & 87.16 & 87.47 & 86.96 & 94.06 & 101.37 & 99.66 \\
\hline $\mathrm{O}=$ & 7.000 & 7.000 & 7.000 & 7.000 & 11.000 & 6.000 & 6.000 \\
\hline $\mathrm{Si}$ & 1.916 & 1.978 & 1.971 & 1.927 & 3.876 & 1.894 & 1.982 \\
\hline $\mathrm{Ti}$ & 0.001 & 0.001 & 0.001 & 0.000 & 0.001 & 0.001 & 0.000 \\
\hline $\mathrm{Al}$ & 0.124 & 0.058 & 0.078 & 0.074 & 0.099 & 0.166 & 0.011 \\
\hline $\mathrm{Cr}$ & 0.036 & 0.017 & 0.033 & 0.018 & 0.009 & 0.022 & 0.001 \\
\hline $\mathrm{Fe}$ & 0.124 & 0.101 & 0.107 & 0.084 & 0.108 & 0.178 & 0.146 \\
\hline $\mathrm{Mn}$ & 0.005 & 0.004 & 0.002 & 0.003 & 0.001 & 0.004 & 0.003 \\
\hline $\mathrm{Ni}$ & 0.002 & 0.003 & 0.006 & 0.004 & 0.004 & 0.004 & 0.003 \\
\hline $\mathrm{Mg}$ & 2.795 & 2.821 & 2.773 & 2.918 & 2.942 & 1.686 & 1.862 \\
\hline $\mathrm{Ca}$ & 0.000 & 0.000 & 0.000 & 0.000 & 0.001 & 0.054 & 0.003 \\
\hline $\mathrm{Na}$ & nd & nd & nd & nd & 0.053 & 0.002 & 0.000 \\
\hline $\mathrm{K}$ & nd & nd & nd & nd & 0.002 & 0.000 & 0.001 \\
\hline Total & 5.003 & 4.983 & 4.971 & 5.028 & 7.096 & 4.011 & 4.012 \\
\hline$X_{M g}$ & 0.958 & 0.965 & 0.963 & 0.972 & 0.965 & 0.905 & 0.927 \\
\hline
\end{tabular}

* Total iron as $\mathrm{FeO}$.

$\mathrm{Nd}$, not determined.

$\mathrm{OE}$ and WS of the sample numbers indicates Oeyama and Wakasa, respectively.

"Ol-parting" means antigorite that penetrates along parting planes of cleavable olivine.

talc \pm tremolite; Zone IV, forsterite + anthophyllite or cummingtonite \pm tremolite; Zone $\mathrm{V}$, forsterite + enstatite \pm tremolite or hornblende. Zone I is almost unaffected by thermal metamorphism. Uda (1984) has reported the occurrence of cummingtonite but we have not found this amphibole, and hence, we cannot divide Zone III and Zone IV in the zonal map (Fig. 2a). The existence of high-grade zones in a southern marginal portion of the Oeyama complex could be caused by subsurface granitic intrusions (Uda, 1984). Although poor exposures in the Wakasa complex makes detailed zonal mapping impossible, our samples have mineral assemblages corresponding to that of Zone I or II of the Oeyama complex.

Distinction between primary and metamorphic phases is based on mode of occurrence and chemistry. Metamorphic olivine is different from primary olivine in that the former commonly shows reticulate or fine-grained granoblastic texture, contains tiny inclusions of magnetite or sulfides, and has highly variable contents of forsterite component (Fo), $\mathrm{NiO}$ and $\mathrm{MnO}$ (Table 1) (e.g., Nozaka, 2003; see the next section for detail). Metamorphic orthopyroxene is different from primary one in that the former shows radial-shaped aggregation or poikiloblastic texture, contains tiny inclusion of magnetite or sulfides and no clinopyroxene lamella, and has lower $\mathrm{Ca}$ and $\mathrm{Cr}$ contents (Table 2) (e.g., Arai, 1975; Uda, 1984; Nozaka and Shibata, 1995). Primary minerals show evidence for deformation such as porphyroclastic texture, elongated shape, kink bands and undulatory extinction, whereas thermally metamorphic minerals look to have formed under static conditions. 
Table 2. (Continued)

\begin{tabular}{|c|c|c|}
\hline Metamorphic zone & II & III \\
\hline Sample & WS0613 & OE08137 \\
\hline Mineral & Tremolite & Tremolite \\
\hline Type & Neoblastic & Granoblastic \\
\hline $\mathrm{SiO}_{2}$ & 56.35 & 58.69 \\
\hline $\mathrm{TiO}_{2}$ & 0.06 & 0.10 \\
\hline $\mathrm{Al}_{2} \mathrm{O}_{3}$ & 0.50 & 0.27 \\
\hline $\mathrm{Cr}_{2} \mathrm{O}_{3}$ & 0.05 & 0.05 \\
\hline $\mathrm{FeO}^{*}$ & 1.99 & 1.26 \\
\hline $\mathrm{MnO}$ & 0.23 & 0.06 \\
\hline $\mathrm{NiO}$ & 0.10 & 0.05 \\
\hline $\mathrm{MgO}$ & 24.26 & 24.43 \\
\hline $\mathrm{CaO}$ & 12.45 & 12.90 \\
\hline $\mathrm{Na}_{2} \mathrm{O}$ & 0.92 & 0.18 \\
\hline $\mathrm{K}_{2} \mathrm{O}$ & 0.07 & 0.00 \\
\hline Total & 96.98 & 97.99 \\
\hline $\mathrm{O}=$ & 23.000 & 23.000 \\
\hline $\mathrm{Si}$ & 7.802 & 7.958 \\
\hline $\mathrm{Ti}$ & 0.006 & 0.010 \\
\hline $\mathrm{Al}$ & 0.082 & 0.043 \\
\hline $\mathrm{Cr}$ & 0.005 & 0.005 \\
\hline $\mathrm{Fe}$ & 0.231 & 0.143 \\
\hline $\mathrm{Mn}$ & 0.027 & 0.007 \\
\hline $\mathrm{Ni}$ & 0.011 & 0.005 \\
\hline $\mathrm{Mg}$ & 5.006 & 4.938 \\
\hline $\mathrm{Ca}$ & 1.847 & 1.874 \\
\hline $\mathrm{Na}$ & 0.247 & 0.047 \\
\hline K & 0.013 & 0.001 \\
\hline Total & 15.277 & 15.031 \\
\hline $\mathrm{X}_{\mathrm{Mg}}$ & 0.956 & 0.972 \\
\hline
\end{tabular}

\section{MODE OF OCCURRENCE AND CHEMICAL COMPOSION OF OLIVINE}

We divided olivine from the Oeyama and Wakasa complexes into five groups on the basis of mode of occurrence: 1) cleavable olivine, 2) uncleavable olivine, 3) neoblastic olivine, 4) reticulate olivine and 5) granoblastic olivine.

Cleavable olivine from Zone I and II commonly occurs as medium-sized (1-5 mm) prismatic, equant or porphyroclastic crystals in serpentinite mylonites (Figs. 3a and b). Porphyroclasts of cleavable olivine, which are spindle-shaped crystals elongated parallel to foliation, are common in rocks containing neoblastic olivine (Fig. 3a), whereas cleavable olivine does not have the porphyroclastic shape in rocks lacking neoblastic olivine. Undulatory extinction is significant in some crystals but insignificant in other crystals of cleavable olivine. Although cleavable olivine occurs in some massive serpentinite without pronounced foliation, lepidoblastic antigorite oc- curs more or less in the same samples or same outcrops. Serpentine pseudomorphs after cleavable olivine, which can be distinguished from bastite after orthopyroxene by parallel arrangement of antigorite blades with mesh texture or the lack of exsolution texture, are abundant in intensively serpentinized rocks.

Parting planes parallel to (010) are the most dominant in cleavable olivine, whereas those to (100) are subordinate and those to (001) are rare. In cases of olivine that shows two sets of parting traces in thin section, degree of cleavability is uneven: one set of parting planes exceeds the other in length, continuity and opening width. Networked fractures are common as well as parting in cleavable olivine. It is noteworthy that at rims of some cleavable olivine crystals, antigorite blades along with adjacent olivine parting planes are bent to the orientation of lepidoblastic antigorite in a matrix (Fig. 3b). The rims of such olivine seem to be bent as well and fractured into small prisms or needles (Fig. 3b). Individual crystals of cleavable olivine from Zone I and II have uniform compositions except for the existence of networked, highly magnesian part (Fig. 3c), which is reticulate olivine described later.

Cleavable olivine from Zone III has parting planes, though not so prominent as in Zone I and II. Kuroda and Shimoda (1967) referred to this type of olivine as "transitional stage" olivine with "indistinct cleavage". The Zone III cleavable olivine looks an aggregate of small crystals (Fig. 3d), which appears to be somewhat similar to granoblastic olivine described later. However, each of the apparently separated small crystals in the aggregate has elongated shape parallel to parting planes (Fig. 3d), and is similar to adjacent small crystals in interference color and extinction position, which, as a whole of the aggregate, are less variable than those of granoblastic olivine within the same size of area of thin section. Small amounts of talc and tremolite are set in the aggregate. Cleavable olivine from Zone III has minute inclusions of magnetite or sulfides and heterogeneous chemical compositions (Fig. 3e).

Uncleavable olivine, which lacks parting, occurs in Zone I and II (Fig. 3f). This type of olivine commonly occurs as medium-sized (1-5 mm) equant grains, showing a slight degree of undulatory extinction. Porphyroclastic texture and coexistence with lepidoblastic antigorite are rare. Uncleavable olivine commonly has networked fractures, which are dominantly filled with lizardite in Zone I and with antigorite in Zone II. In strongly serpentinized rocks, serpentine (mainly lizardite) pseudomorphs after uncleavable olivine form mesh texture.

Neoblastic olivine occurs as small $(<0.1 \mathrm{~mm})$ grains in close association with lepidoblastic antigorite in the 

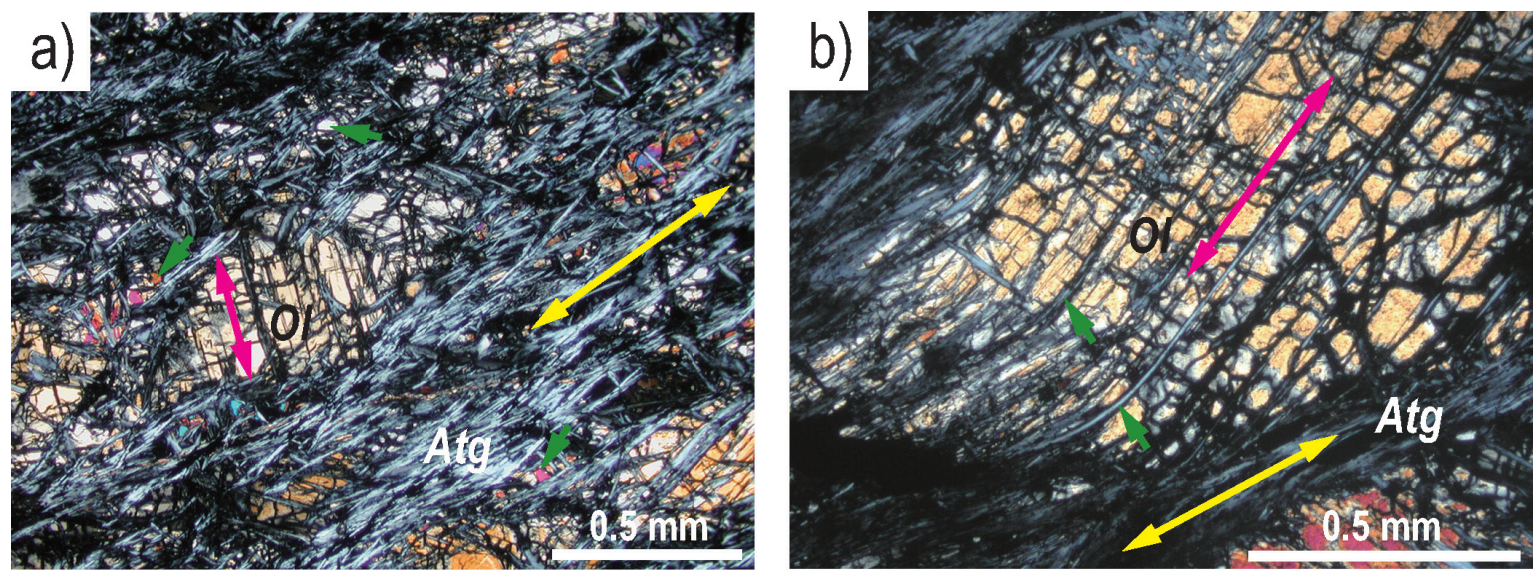

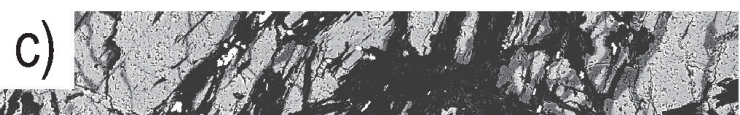

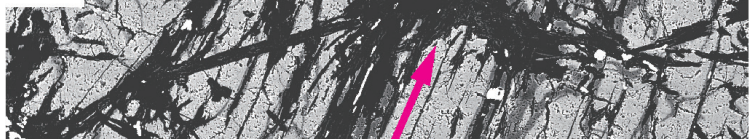

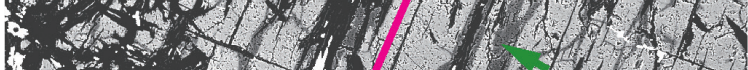

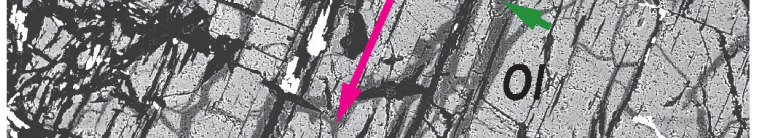
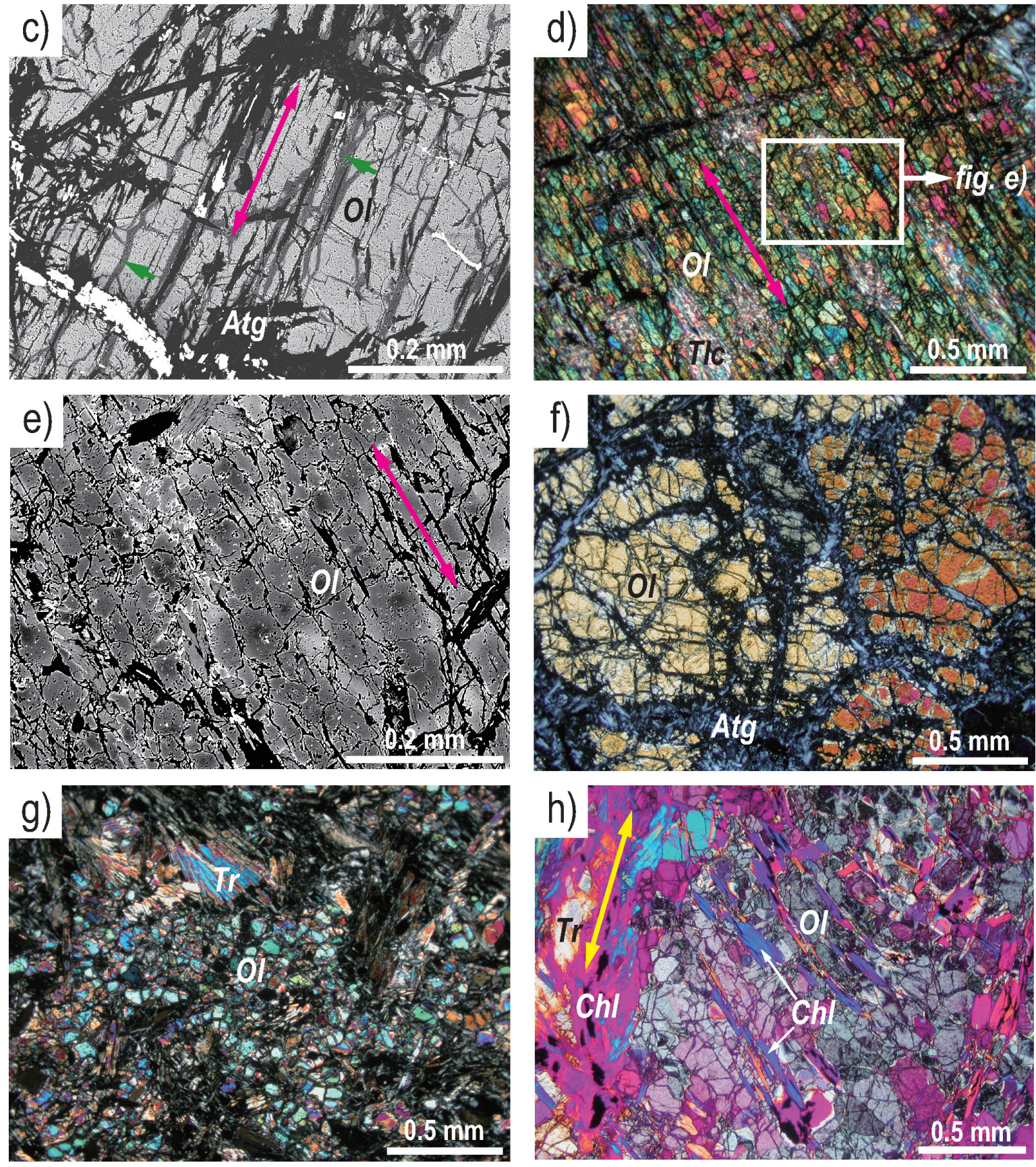
matrix of serpentinite mylonites (Fig. 3a). Neoblastic olivine forms aggregates elongated parallel to foliation, or forms tails of porphyroclastic olivine along with similarly small-sized tremolite and chlorite. Neoblastic olivine has homogeneous compositions and no magnetite inclusions like cleavable and uncleavable olivine.

Reticulate olivine forms a vein or network that invades or encloses crystals of cleavable, uncleavable or neoblastic olivine, or occurs along parting planes of cleavable olivine in Zone II (Fig. 3c). Reticulate olivine is clearly different from the host olivine in composition. This type of olivine commonly occurs in weakly metamorphosed serpentinites (Nozaka, 2003, 2005).

Granoblastic olivine occurs in Zones III-V and locally in Zone II. It commonly forms aggregates of small $(0.1-0.5 \mathrm{~mm})$ grains with variable interference colors and extinction positions, and without undulatory extinction. Its association with talc and tremolite is common in Zone III (Fig. 3g). Similarly small-sized olivine in poikiloblastic orthopyroxene in Zone V is included in this group. Minute inclusions of magnetite with a small amount of sulfides and heterogeneous chemical compositions are common characteristics of granoblastic olivine.

Figure 4 shows variations of $\mathrm{NiO}$ versus Fo contents of olivine. Cleavable and uncleavable types of olivine from Zone I and II have Fo contents that are variable between samples but almost uniform in each sample, regardless of crystal shape (i.e., porphyroclastic, prismatic or equant). Most of the cleavable and uncleavable olivine from Zone I and II are plotted within or NiO-poor side of the mantle olivine array proposed by Takahashi et al. (1987). Neoblastic olivine has compositions similar to cleavable or uncleavable olivine from the same samples. Cleavable olivine from Zone III, reticulate olivine and granoblastic olivine have highly variable and very different compositions from those of cleavable, uncleavable and neoblastic olivine from Zone I and II (Fig. 4). In each

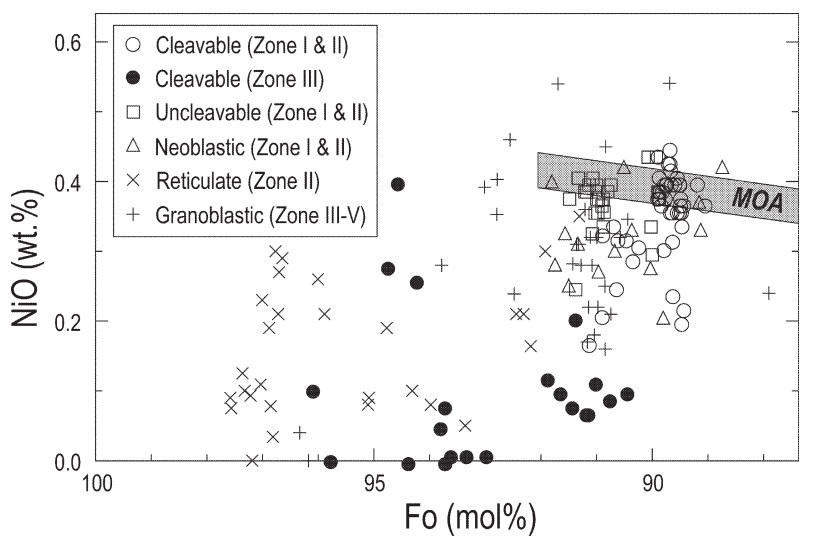

Figure 4. NiO versus Fo contents of olivine. Several grains of olivine in each of 25 samples are plotted. MOA, mantle olivine array proposed by Takahashi et al. (1987).

sample, the variation range of $\mathrm{Fo}$ and $\mathrm{NiO}$ content is $<0.5$ $\mathrm{mol} \%$ and $0.05-0.1 \mathrm{wt} \%$, respectively, in cleavable, uncleavable and neoblastic olivine from Zone I and II, whereas it is $2-9 \mathrm{~mol} \%$ and $0.2-0.4 \mathrm{wt} \%$ in Zone III cleavable olivine, and reticulate and granoblastic olivine.

\section{SERPENTINE MINERALS}

In some representative samples, serpentine polymorphs were identified with Raman scattering in the range of $200-1100 \mathrm{~cm}^{-1}$ (Fig. 5). Among the Raman-shift peaks, which are caused by vibration or stretching vibration of atomic bonds, translation motion, cation substitution and an additional effect of epoxy resin used for thin-section preparation, the peaks around $1045 \mathrm{~cm}^{-1}$ and $370-390$ $\mathrm{cm}^{-1}$ can be used for the distinction between serpentine polymorphs (Rinaudo et al., 2003; Groppo et al., 2006). The results of Raman spectroscopy are consistent with the textural characteristics of serpentine minerals, and have confirmed that mode of occurrence observed under the

\footnotetext{
Figure 3. Modes of occurrence of olivine in serpentinites and peridotites. Yellow and red arrow indicates the direction of foliation and parting planes of olivine, respectively. (a) Photomicrograph of a serpentinite mylonite from the Wakasa complex (crossed polars). Olivine porphyroclasts $(\mathrm{Ol})$ and neoblasts (green arrows) are set in a matrix of lepidoblastic antigorite (Atg). (b) Photomicrograph of a grain of cleavable olivine from the Wakasa complex (crossed polars). Antigorite (green arrows) formed along parting planes is bent at olivine (Ol) rim to be parallel to the foliation defined by preferred orientation of the matrix antigorite (Atg). Networked fractures of olivine are commonly filled with lizardite. (c) Back-scattered electron image of cleavable olivine from Zone II of the Oeyama complex. Irregular-shaped networks of olivine, i.e., reticulate olivine (green arrows) are darker than host olivine $(\mathrm{Ol})$ due to its more magnesian compositions. The brightest mineral is magnetite. (d) Photomicrograph of cleavable olivine from Zone III of the Oeyama complex (crossed polars). Talc (Tlc) and tremolite (invisible in this figure) are formed within the cleavable olivine. (e) Back-scattered electron image of a part of Figure 3d. Olivine has heterogeneous composition and includes minute grains of magnetite (brightest particles). (f) Photomicrograph of equant uncleavable olivine (Ol) from Zone II of the Oeyama complex (crossed polars). Fractures in olivine are mainly filled with antigorite aggregates. (g) Photomicrograph of granoblastic olivine (Ol) and tremolite (Tr) from Zone III of the Oeyama complex (crossed polars). (h) Photomicrograph of a peridotite mylonite from the Happo ultramafic complex (crossed polars with gypsum plate). Porphyroclastic olivine (Ol) is penetrated by parallel blades of chlorite (Chl, bluish colors), which is partially replaced by serpentine (yellowish colors). Subgrains of the olivine porphyroclast are visible by the slight difference of interference color.
} 

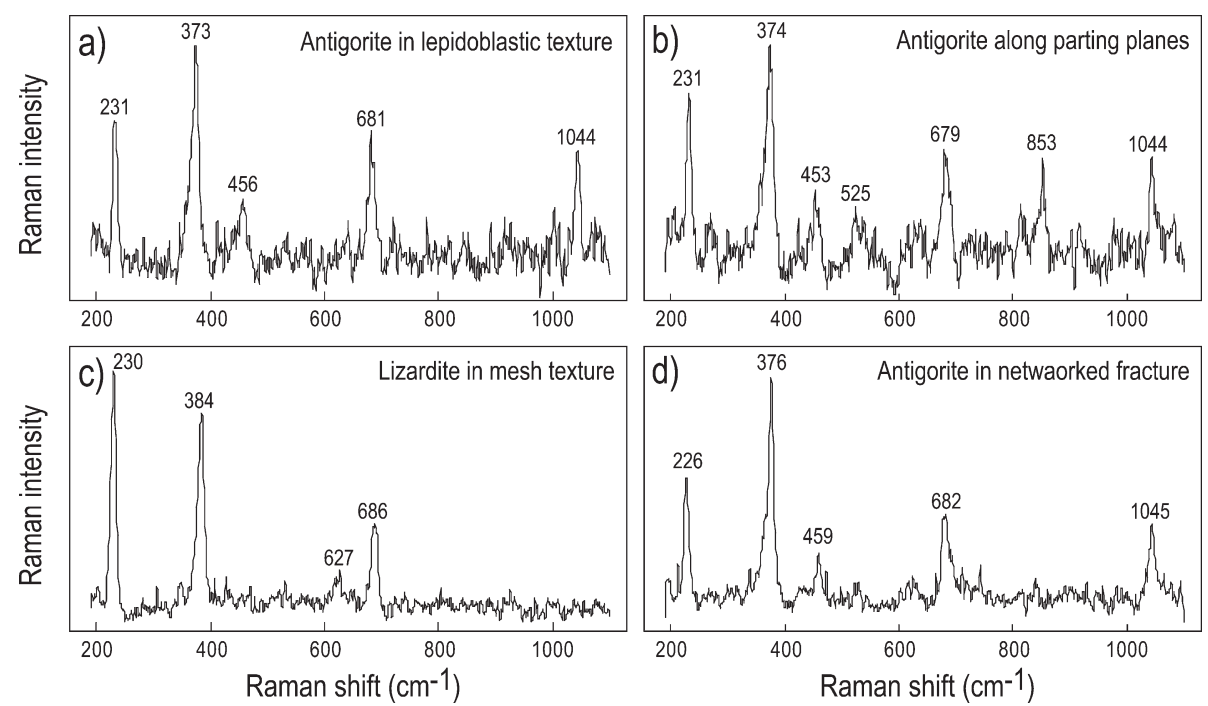

Figure 5. Micro-Raman spectra of serpentine minerals. (a) Antigorite forming lepidoblastic texture in a serpentinite mylonite with Zone I mineral assemblage from the Wakasa complex. (b) Antigorite along parting planes of olivine from Zone II of the Oeyama complex. (c) Lizardite forming a pseudomorph after olivine with mesh texture from Zone II of the Oeyama complex. (d) Antigorite forming an aggregate that fills networked fractures of uncleavable olivine from Zone II of the Oeyama complex. microscope is still useful for the identification of serpentine minerals (e.g., O’Hanley, 1996).

It is antigorite that forms lepidoblastic texture in serpentinite mylonites and occurs along parting planes of cleavable olivine from Zone I and II (Figs. 5a and 5b). These results are consistent with the description of Uda (1984) but contradict Aikawa (1981), who reported chrysotile along the olivine parting planes. It is evident that the blade-shaped crystals of serpentine in our serpentinite mylonites are antigorite, but we cannot rule out the possibility that very thin films of chrysotile fill tightly opened parting spaces of olivine.

Lizardite was detected from mesh-pseudomorphs after olivine and fillings of networked fractures of olivine in Zone I, whereas both antigorite and lizardite were detected from the mesh pseudomorphs and fracture fillings in Zone II (Figs. 5c and 5d).

\section{STRUCTURAL RELATIONSHIP BETWEEN CLEAVABLE OLIVINE AND SERPENTINITE MYLONITES}

Fabric analyses of serpentinite mylonites suggest a relationship of cleavable olivine with deformation, although the relatively coarse-grained nature of rocks and decomposition of olivine by serpentinization have limited the reliability of interpretation to some extent. Poles of dominant parting planes, most of which are parallel to (010) of olivine, tend to be concentrated in NE-SW and NW-SE direction in the Oeyama and Wakasa complexes, respectively, showing a harmony with the distribution of poles of foliation (Fig. 6a). To avoid the effect of perturbation by local faulting and folding, the relationship between the parting and foliation was examined in representative sam- ples. As shown by Figure $6 \mathrm{~b}$, the poles of parting planes tend to be distributed around a plane perpendicular to foliation.

\section{DISCUSSION}

\section{Variation of olivine composition and effect of thermal metamorphism}

Cleavable and uncleavable olivine from Zone I and II have chemical compositions plotted within or NiO-poor side of the mantle olivine array (Fig. 4), suggesting that they were originated in residual peridotites and cumulates from basaltic melts (Takahashi et al., 1987). The effect of thermal metamorphism on these types of olivine looks to be almost lacking.

Neoblastic olivine has compositions similar to porphyroclasts of cleavable or uncleavable olivine in the same sample. Rocks characterized by such a bimodal distribution of grain size of olivine without significant compositional variations are referred to as peridotite mylonites, which were produced by plastic deformation associated with dynamic recrystallization (e.g., Nozaka, 2005).

Compared with the olivine that looks to retain primary compositions, reticulate olivine and granoblastic olivine have more variable $\mathrm{Fo}$ and $\mathrm{NiO}$ contents. In agreement with Uda (1984), we interpret these types of olivine as products of thermal metamorphism after serpentinization, because they are very similar in chemical composition, mode of occurrence and spatial distribution to the metamorphic olivine in other thermally metamorphosed ultramafic complexes (e.g., Arai, 1975; Nozaka, 2003, 2005). 


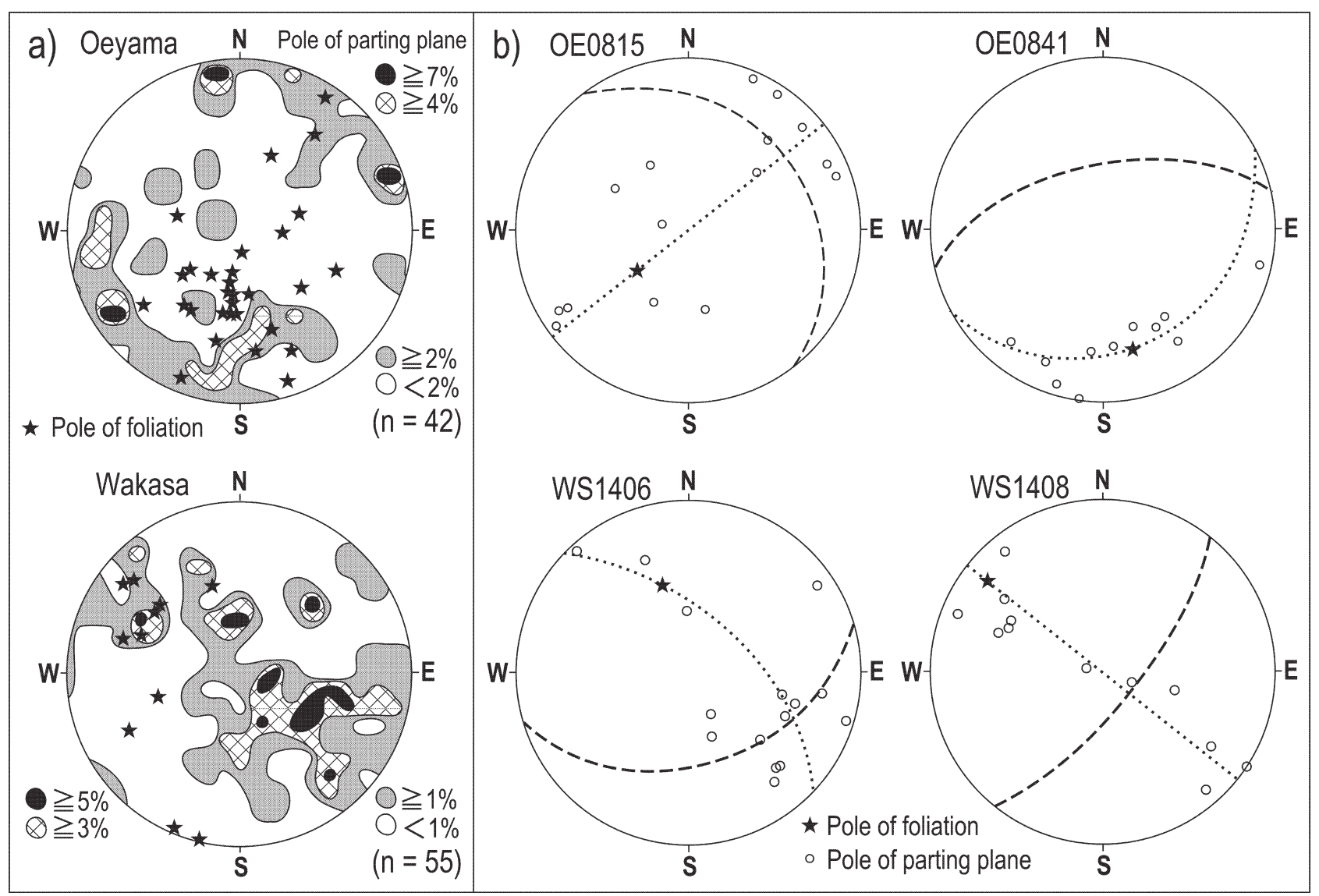

Figure 6. Equal area lower-hemisphere projections of poles of parting planes of olivine and foliation of serpentinite mylonites. (a) Projections of all the measured poles of the Oeyama and Wakasa complexes. Contours represent distribution density of the poles of parting planes per $1 \%$ area. (b) Projections of the poles in individual samples (sample number is shown at upper-left of each projection; OE and WS indicates samples from the Oeyama and Wakasa, respectively). Poles of olivine parting planes tend to be distributed around a plane (dotted great circle) that is perpendicular to the foliation surface (dashed great circle).

Cleavable olivine from Zone III has highly heterogeneous compositions similar to the reticulate and granoblastic olivine. It is most likely that this olivine have the same origin as cleavable olivine in Zone I and II, and has been affected by thermal metamorphism after partial serpentinization. The parting traces of cleavable olivine from Zone III are filled with thin films of serpentine, which was formed by alteration after thermal metamorphism. Although we have not found cleavable olivine that looks to retain primary compositions in Zone III, it is common that original chemistry of olivine is lost in similar-grade zones (Nozaka, 2003). This is probably a result of progress of cation diffusion within olivine crystals during thermal metamorphism. Kuroda and Shimoda (1967) and Uda (1984) have found that cleavable olivine with weak parting occurs in Zone II close to Zone III, but it is stressed here that cleavable olivine actually occurs in Zone III, where talc and tremolite occur (Fig. 3d).

\section{Conditions for mylonitization}

Most of serpentinite mylonites from the Oeyama ophiolite contain neoblastic olivine as well as lepidoblastic antigorite. The antigorite have $\mathrm{X}_{\mathrm{Mg}}(=\mathrm{Mg} / \mathrm{Mg}+\mathrm{Fe})$ around 0.96 or higher (Table 2). Metamorphic olivine that coexists with such magnesian antigorite usually has Fo contents greater than $92 \mathrm{~mol} \%$ (Trommsdorff and Evans, 1972, 1974). Compared with the olivine coexisting with antigorite, neoblastic olivine in the Oeyama ophiolite has lower Fo contents $(<92 \mathrm{~mol} \%)$, which are similar to those of primary igneous olivine (Table 1 and Fig. 4). Consistently, neoblastic tremolite that coexists with the olivine neoblasts and chlorite at tails of olivine porphyroclasts is less magnesian than granoblastic tremolite of thermally metamorphic origin (Table 2). The neoblastic tremolite is similar in composition to a series of retrograde tremolite, and its relatively low $\mathrm{Si}$ and high $\mathrm{Al}$ contents suggest a formation condition at higher temperatures than the condition for thermally metamorphic tremolite as the case of 
the Happo complex (Nozaka, 2005).

From the textural and mineralogical evidence it is considered that the serpentinite mylonites in the Oeyama ophiolite was formed by two stages of plastic deformation like those of the Happo ultramafic complex (Nozaka, 2005). The association of neoblastic olivine with tremolite and chlorite suggests that the earlier deformation took place at temperatures of $700-800{ }^{\circ} \mathrm{C}$ under hydrous conditions (Nozaka, 2005). On the other hand, the formation of lepidoblastic antigorite suggests that the later deformation was associated with relatively high-temperature (up to $600{ }^{\circ} \mathrm{C}$ ) serpentinization (Nozaka, 2005). The serpentinite mylonites from the Oeyama ophiolite and the Happo complex lack evidence for prograde regional metamorphism associated with deformation, and commonly show the parallelism of structure between high-temperature (olivine + tremolite + chlorite) and low-temperature (antigorite + magnetite) assemblages, suggesting a sequential deformation and retrogression. Although the serpentinite mylonites have no constraint for pressure conditions, the lower-temperature event of sequential deformation probably took place at a shallower level during a course of tectonic movement. Because more intensely mylonitized peridotites tend to be subjected to more intense overprint of high-temperature serpentinization, the two-stage deformation seems to have been promoted by elevated permeability during exhumation of the mantle peridotites.

\section{Formation of cleavable olivine}

Hypotheses that have been proposed for the genesis of cleavable olivine in the Oeyama ophiolite can be categorized into three groups: crystallization under high pressures (Kuroda and Shimoda, 1967), deformation related to tectonic movement (Aikawa, 1981) and annealing after thermal metamorphism (Uda, 1984). Among them, the hypothesis of high-pressure crystallization and resulting unusual crystal structure of olivine (Kuroda and Shimoda, 1967; Kuroda, 1969) have been disproved by advanced X-ray analyses of Aikawa (1981) and Aikawa and Tokonami (1987).

The main basis of the hypothesis of annealing after thermal metamorphism is the following observations: parting planes cut metamorphic reticulate olivine; cleavable olivine occurs exclusively in the forsterite + antigorite zone (Zone II in our zonal map); and the parting planes represent cellular walls with high dislocation density. From these observations, Uda (1984) has considered that cleavable olivine formed in the forsterite + antigorite zone by arrangement of dislocations during annealing after thermal metamorphism. Although Uda (1984) provided reliable data sets and made an important contribution to our understanding thermal metamorphism of serpentinites, his hypothesis on cleavable olivine seems to be based on misinterpretations as follows. 1) Metamorphic reticulate olivine appears to be cut by parting planes but, in fact, is cut by serpentine films that fill parting spaces (Fig. 6 and Plate I-2 of Uda, 1984). This microscopic relationship just represents the intersection of metamorphic olivine and parting planes, but does not suggest a temporal sequence of their formation. In addition, it is possible that the serpentine films postdated the formation of reticulate olivine, but this is not necessarily true if the serpentine is antigorite, because temperature conditions for Zone II should allow the coexistence of olivine and antigorite. Antigorite formed along parting planes (as shown in Fig. $3 c)$ could predate or coexist with reticulate olivine. 2) The temperature conditions as low as $400{ }^{\circ} \mathrm{C}$ proposed by Uda (1984) seem to be unreasonably low for the arrangement of dislocations in olivine, because the recovery of dislocation after heating are the same process as dislocation climb, which is insignificant at temperatures less than 800 ${ }^{\circ} \mathrm{C}$ (Toriumi and Karato, 1978; Hirth, 2002; Katayama and Karato, 2008). 3) Even if the arrangement of dislocations after thermal metamorphism was possible, we could see no reason why the metamorphic olivine, which formed under static conditions, should have dense dislocations as deformed olivine has, and why the dislocations concentrated on the same plane as a parting plane of host olivine. 4) Uda (1984) has observed the coexistence of cleavable and uncleavable olivine within the same sample, and has ascribed the presence and absence of parting to the difference of dislocation density between olivine crystals before thermal metamorphism; however, the cause of this difference has not been addressed. 5) Uda (1984) has accounted for the lack of cleavable olivine in high-grade zones in terms of parallelism between the olivine-antigorite reaction curve and cooling paths of metamorphic zones (Fig. 19 of Uda, 1984). However, this explanation seems to be unacceptable. Given that the main cause of the cooling of contact aureoles was thermal conduction, a higher-grade zone should have a cooling rate greater than lower-grade zones as suggested by simplified thermal diffusion models (e.g., Jaeger, 1968). Because there is no evidence for difference in water activity between zones after thermal metamorphism, antigorite along with the parting planes of olivine should be formed in higher-grade zones as well as lower-grade zones if the cause of parting was retrogression after thermal metamorphism.

We also present clear evidence against the hypothesis that cleavable olivine was formed by processes related to thermal metamorphism. 1) As shown in Figure 2b, the distribution of cleavable olivine looks to have no relation 
with metamorphic grade, which contradicts the observation of Uda (1984). 2) The deformation of antigorite and cleavable olivine (Fig. 3b) suggests the earlier formation of the parting before thermal metamorphism, by which most of metamorphic minerals were formed under static conditions. 3) Such a mode of occurrence and chemical composition as shown by Figures 3d, 3e and 4 suggest the effect of thermal metamorphism on preexisting cleavable olivine that was partially serpentinized. The obscurity of parting of olivine in Zones III-V is ascribed to decomposition of parting space-filling antigorite by thermal metamorphism. In olivine crystals from high-grade zones, Uda (1984) has found the existence of cellular structures composed of walls of high dislocation density, which is similar to those found in cleavable olivine from low-grade zones. Much more straightforward explanation for this fact than the unrealistic parallel cooling paths of metamorphic zones is that these dislocation structures are the remains inherited from deformation that took place before the thermal metamorphism. The dislocations in olivine could be diffused by heating during thermal metamorphism but this process could be less efficient, and consequently, planar arrangement of dislocations was retained more in lower-grade zones. This is the reason why cleavable olivine that has retrograde serpentine films along parting traces occurs in Zone III and does not in Zone V.

The preferred orientation of the parting planes of olivine (Fig. 6) indicates a link of cleavable olivine to deformation. Because the parting planes of olivine commonly have intervening antigorite blades that are locally bent to the direction of foliation, the parting seems to have been generated before syntectonic serpentinization. On the other hand, the parting does not seem to have a direct genetic link with the high-temperature deformation by which peridotite mylonites were produced, because all grains of cleavable olivine do not show porphyroclastic texture. In the Happo complex, which have rocks less serpentinized than those the Oeyama and Wakasa complexes, olivine porphyroclasts in peridotite mylonites have no clear parting. A likely explanation for all the observations is that the parting of olivine was generated in and around localized shear zones after the formation of peridotite mylonites and before the formation of serpentinite mylonites.

The parting planes of olivine have high dislocation density (Aikawa, 1981; Uda, 1984). The dominant mechanism of deformation of olivine under temperatures as low as $700-800{ }^{\circ} \mathrm{C}$, at which the mylonitization of the peridotites took place, is dislocation glide under a high differential stress (Hirth, 2002; Katayama and Karato, 2008). The concentration of dislocations on certain planes is caused by recovery processes after deformation (e.g., Toriumi and Karato, 1978). Such a plane with high dislo- cation density could be a favorable site for alteration. However, it is evident from microscopic observations that the parallel arrangement of parting planes of olivine does not correspond with the distribution of subgrain boundaries. An analogy to the cleavable olivine is olivine porphyroclasts in a peridotite mylonite from the Happo complex (Fig. 3h). The porphyroclasts, which have subgrains but no clear parting planes, are penetrated by parallel chlorite blades that are slightly bent to the direction of foliation, suggesting that a set of subparallel subgrain boundaries provided the sites of the formation of chlorite under a differential stress. Because the dominant parting planes of cleavable olivine commonly have intervening antigorite blades, it is considered that preferential alteration along a set of parallel dislocation walls or subparallel subgrain boundaries and the penetration of growing antigorite blades under a differential stress produced cleavable olivine with pronounced parallel parting. The dominant slip system is (010) [001] during the formation of peridotite mylonites in the Happo complex (Nozaka, 2005). This is the probable cause of the dominance of (010) and rarity (001) parting planes in cleavable olivine.

Figure 7 represents a schematic model of the formation of cleavable olivine through a sequence of deformation and alteration. Peridotite mylonites formed at an early stage of deformation (Fig. 7a) in localized shear zones, where supply of water could enhance the dislocation glide of olivine with dominant slip system (010) [001] (Katayama and Karato, 2006, 2008). Subsequent recovery processes yielded subgrain boundaries in porphyroclasts and walls with high dislocation density in gently deformed crystals (Fig. 7b). These strongly or gently deformed olivine crystals are embryonic but not yet typical cleavable olivine, which has prominent parallel parting. During a subsequent stage of alteration and almost synchronous plastic deformation, deformed olivine crystals were altered along a set of parallel planes [dominantly (010) planes] with high dislocation density (dislocation walls) and penetrated by parallel antigorite blades, and then the antigorite blades were bent parallel to foliation and grew together with matrix lepidoblastic antigorite (Fig. 7c). Simultaneously, cleaved flakes of olivine probably glided and rotated with the support of lubricant antigorite. The fabric of cleavable olivine (Fig. 6) was probably strengthened to some extent by the rotation of the cleaved flakes. The rims of cleavable olivine crystals are bent as well as the antigorite blades, but their appearance suggests a brittle fracturing rather than plasticity (Fig. 3b), probably reflecting low temperature conditions at this stage of deformation.

Syntectonic high-temperature (around $400-600{ }^{\circ} \mathrm{C}$; Nozaka, 2005) serpentinization, during which intervening 

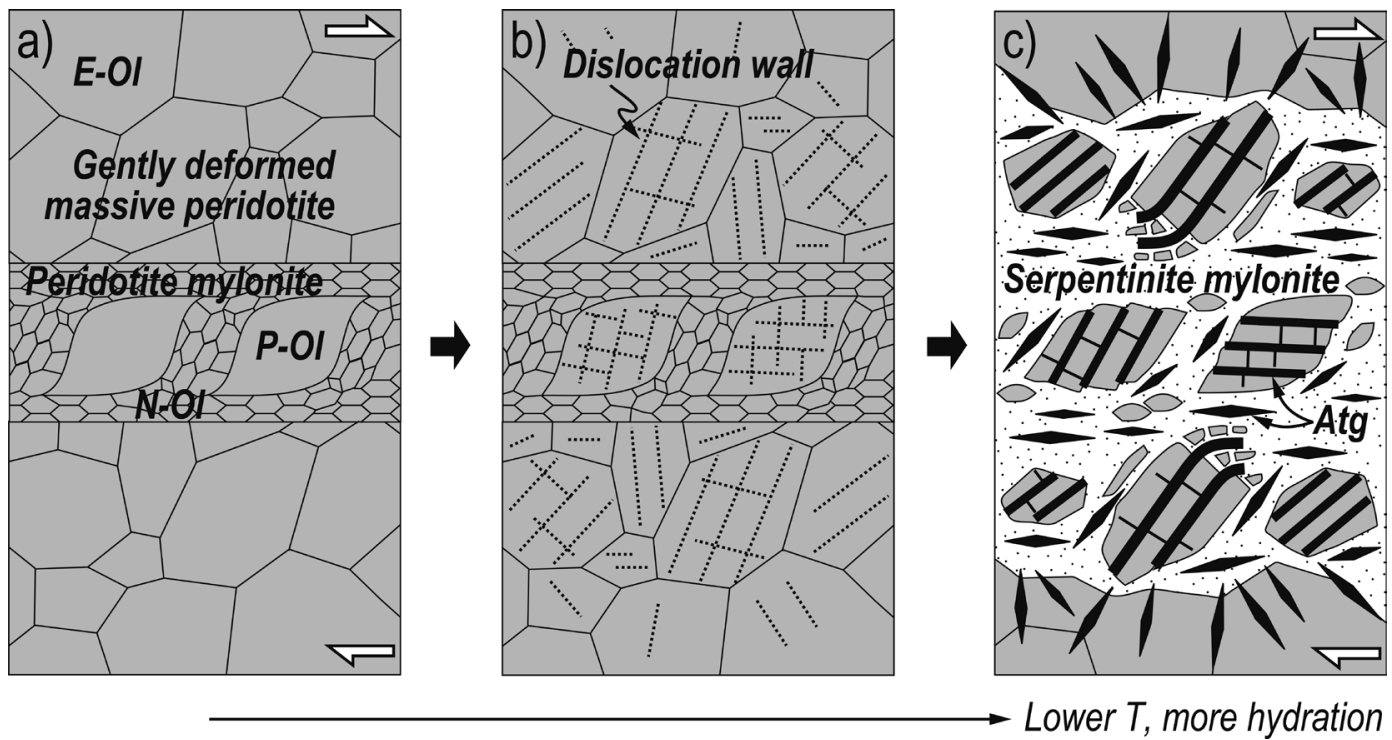

Figure 7. Schematic model of the formation of cleavable olivine during a sequence of deformation and alteration of peridotites. (a) Formation of peridotite mylonites in localized shear zones under relatively high-temperature and hydrous conditions at an early stage of deformation. Abbreviations: E-Ol, equant olivine; $\mathrm{N}-\mathrm{Ol}$, neoblastic olivine; $\mathrm{P}-\mathrm{Ol}$, porphyroclastic olivine. The peridotite mylonites contain chlorite and tremolite. White arrow indicates a sense of shear. (b) Formation of subgrain boundaries or cellular walls with high dislocation density (dotted line) by recovery processes after the early stage deformation. (c) Formation of cleavable olivine and serpentinite mylonites by syntectonic high-temperature serpentinization. Antigorite blade (Atg) formation associated with glide and rotation of cleaved flakes of olivine widened certain sets of parting planes. Bending of the antigorite blades along parting planes and brittle fracturing at rims of cleavable olivine took place at a late time of this stage of deformation.

antigorite grew and brought the parting into prominence, was a necessary condition for the formation of cleavable olivine. Another condition could be the original lithology of serpentinites. Kuroda and Shimoda (1967) have pointed out that cleavable olivine occur in dunite and does not in harzburgite in the Oeyama complex. Most of serpentinite mylonites in the Oeyama and Wakasa complexes indeed look to be originally dunite. Although the apparent absence of cleavable olivine in harzburgite could just reflect the rarity of this type of rock in the Oeyama complex, it seems to be possible as well that deformation tends to be localized in rocks richer in olivine, which is the mineral most susceptible to plastic deformation and alteration under relatively low-temperature conditions.

The concentration of the poles of parting planes on a plane perpendicular to foliation (Fig. 6b) suggests the existence of a rotation axis of olivine crystals during deformation. The intersections of foliation and the plane on which parting poles are concentrated (Fig. 6b) and the general trends of foliation and parting planes (Fig. 6a) seem to indicate the directions of shear stress. The dominant direction of shearing is NE-SW and NW-SE in the Oeyama and Wakasa complex, respectively, and it is somewhat oblique to the elongation axis of each complex (Fig. 1). Such a structural fabric probably reflects regional tectonics at the time of exhumation of the mantle rocks.
In addition, asymmetric crystals of cleavable olivine (Fig. $3 b)$ can be a useful indicator of a sense of shear.

The Oeyama ophiolite and the Happo complex are thought to be derived from the upper mantle of a suprasubduction zone (Ishiwatari and Tsujimori, 2003; Khedr and Arai, 2010). The commonness of cleavable olivine at supra-subduction zones is also suggested by recent reports of its occurrence in serpentinized peridotites from the seafloor (Ishii et al., 1992; Ohara and Ishii, 1998; Niida et al., 2001; Murata et al., 2009). Cleavable olivine in these peridotites was probably formed by a similar mechanism. We expect that cleavable olivine in serpentinized peridotites sampled from other ophiolites and the seafloor will be useful for further understanding of regional tectonics of supra-subduction zones.

\section{CONCLUSIONS}

Cleavable olivine was produced during a sequence of localized plastic deformation and alteration of peridotites at temperatures around $600{ }^{\circ} \mathrm{C}$ or lower. The parting is likely to have derived from dislocation arrangement by recovery processes after plastic deformation of hydrous peridotites and have been brought into prominence during syntectonic serpentinization. The preferred orientation of the parting planes suggests that cleavable olivine is a potential in- 
dicator of regional tectonics of the upper mantle at suprasubduction zones.

\section{ACKNOWLEDGMENTS}

We are grateful to Professor J. Takada and Dr. M. Nakanishi of Okayama University for permission and assistance for the usage of the Raman spectroscope system at their laboratory. Our thanks also go to N. Fujiwara, S. Kondoh, S. Nitta and Y. Yoshii for assistance in field and laboratory works. The manuscript benefited from helpful comments of the journal reviewers S. Arai and T. Tsujimori, and the associate editor A. Ishiwatari. This study was supported by funding from the Wesco Scientific Promotion Foundation.

\section{REFERENCES}

Aikawa, N. (1981) On the olivine with well-developed partings. The Journal of the Japanese Association of Mineralogists, Petrologists and Economic Geologists, 76, 61-67 (in Japanese with English abstract).

Aikawa, N. and Tokonami, M. (1987) Crystal structure and cation distribution of "cleavable" olivines. Mineralogical Journal, 13, 271-279.

Arai, S. (1975) Contact metamorphosed dunite-harzburgite complex in the Chugoku district, western Japan. Contributions to Mineralogy and Petrology, 52, 1-16.

Arai, S. (1980) Dunite-harzburgite-chromitite complexes as refractory residue in the Sangun-Yamaguchi zone, western Japan. Journal of Petrology, 21, 141-165.

Arai, S. and Yurimoto, H. (1995) Possible sub-arc origin of podiform chromitites. Island Arc, 4, 101-111.

Bence, A.E. and Albee, A.L. (1968) Empirical correction factors for the electron microanalysis of silicates and oxides. Journal of Geology, 76, 382-403.

Chihara, K. (1989) Tectonic significance of jadeitite in Hida Marginal Belt and Sangun Metamorphic Belt. Memoirs of the Geological Society of Japan, 33, 37-51 (in Japanese with English abstract).

Groppo, C., Rinaudo, C., Cairo, S., Gastaldi, D. and Compagnoni, R. (2006) Micro-Raman spectroscopy for a quick and reliable identification of serpentine minerals from ultramafics. European Journal of Mineralogy, 18, 319-329.

Hawkes, H.E.Jr. (1946) Olivine from northern California showing perfect cleavage. American Mineralogist, 31, 276-283.

Hirth, G. (2002) Laboratory constraints on the rheology of the upper mantle. In Plastic deformation in minerals and rocks (Karato, S. and Wenk, H. Eds.). pp. 420, Reviews in Mineralogy and Geochemistry, 51, Mineralogical Society of America, Washington, D.C., 97-120.

Igi, S. and Kuroda, K. (1965) Geological map of Japan, 1:50,000; Oeyama. Geological Survey of Japan, Tsukuba.

Ishii, T., Robinson, P.T., Maekawa, H. and Fiske, R. (1992) Petrological studies of peridotites from diapiric serpentinite seamounts in the Izu-Ogasawara-Mariana forearc, Leg 125. In Proceedings of the Ocean Drilling Program, Scientific Results (Fryer, P., Pearce, J.A., Stokking, L.B., et al. Eds.), 125, 445-485.
Ishiwatari, A. (1989) Ophiolites of Japan. Journal of Geography, 98, 290-303 (in Japanese with English abstract).

Ishiwatari, A. (1990) Yakuno ophiolite and related rocks in Maizuru terrane. In Pre-Cretaceous terranes of Japan (Ichikawa, K., Mizutani, S., Hara, I., Hada, S. and Yao, A. Eds.). Publication of IGCP \#224, Osaka City University, Osaka, 109120.

Ishiwatari, A. and Tsujimori, T. (2003) Paleozoic ophiolites and blueschists in Japan and Russian Primorye in the tectonic framework of East Asia: A synthesis. Island Arc, 12, 190-206.

Jaeger, J.C. (1968) Cooling and solidification of igneous rocks. In Basalts. The Poldervaart treatise on rocks of basaltic composition, Volume 2 (Hess, H.H. and Poldervaart, A. Eds.). pp. 862 (including Volume 1), Wiley \& Sons, New York, 503-536.

Katayama, I. and Karato, S. (2006) Effect of temperature on the B- to C-type olivine fabric transition and implication for flow pattern in subduction zones. Physics of the Earth and Planetary Interiors, 157, 33-45.

Katayama, I. and Karato, S. (2008) Low-temperature, high-stress deformation of olivine under water-saturated conditions. Physics of the Earth and Planetary Interiors, 168, 125-133.

Khedr, M.Z. and Arai, S. (2010) Hydrous peridotites with Ti-rich chromian spinel as a low-temperature forearc mantle facies: evidence from the Happo-O'ne metaperidotites (Japan). Contributions to Mineralogy and Petrology, 159, 137-157.

Kuroda, Y. (1969) Crystal structure of olivine and its chemical bonds. The Journal of the Japanese Association of Mineralogists, Petrologists and Economic Geologists, 62, 66-79 (in Japanese with English abstract).

Kuroda, Y. and Shimoda, S. (1967) Olivine with well-developed cleavages-its geological and mineralogical meanings. Journal of the Geological Society of Japan, 73, 377-388.

Kuroda, Y., Kurokawa, K., Uruno, K., Kinugawa, T., Kano, H. and Yamada, T. (1976) Staurolite and kyanite from epidote-hornblende rock in the Oeyama (Komori) ultramafic mass, Kyoto Prefecture, Japan. Journal of the Association for the Geological Collaboration in Japan (Chikyu Kagaku), 30, 331-335.

Kurokawa, K. (1975) Discovery of kyanite from epidote-amphibolite in the Oeyama ultramafic mass, Inner Zone of Southwest Japan. Journal of the Geological Society of Japan, 81, 273-274.

Kurokawa, K. (1985) Petrology of the Oeyama ophiolitic complex in the Inner Zone of Southwest Japan. Science Reports of Niigata University. Series E, 6, 37-113.

Kutty, T.R.N., Subbanna, G.N. and Anantha Iyer, G.V. (1983) Electron microscopy of olivine with perfect cleavage. Proceedings of Indian Academy of Sciences, 92, 283-295.

Matsumoto, I., Arai, S., Muraoka, H., and Yamauchi, H. (1995) Petrological characteristics of the dunite-harzburgite-chromitite complexes of the Sangun zone, Southwest Japan. Journal of Mineralogy, Petrology and Economic Geology, 90, 13-26 (in Japanese with English abstract).

Matsumoto, I. and Arai, S. (2001) Morphological and chemical variations of chromian spinel in dunite-harzburgite complexes from the Sangun zone (SW Japan): implications for mantle/melt reaction and chromitite formation processes. Mineralogy and Petrology, 73, 305-323.

Murata, K., Maekawa, H., Yokose, H., Yamamoto, K., Fujioka, K., Ishii, T., Chiba, H. and Wada, Y. (2009) Significance of serpentinization of wedge mantle peridotites beneath Mariana forearc, western Pacific. Geosphere, 5, 90-104.

Nakamura, Y. and Kushiro, I. (1970) Compositional relations of 
coexisting orthopyroxene, pigeonite and augite in a tholeiitic andesite from Hakone volcano. Contributions to Mineralogy and Petrology, 26, 265-275.

Niida, K., Yuasa, M., Nishimura, A., Fujiwara, T. and Watanabe, T. (2001) Serpentinites from Ohmachi Seamount: Origin of basement lithosphere of the Izu-Ogasawara Arc. JAMSTEC Journal of Deep Sea Research, 19, 77-86 (in Japanese).

Nishimura, Y. (1998) Geotectonic subdivision and areal extent of the Sangun belt, Inner Zone of Southwest Japan. Journal of Metamorphic Geology, 16, 129-140.

Nishimura, Y. and Shibata, K. (1989) Modes of occurrence and $\mathrm{K}-\mathrm{Ar}$ ages of metagabbroic rocks in the "Sangun metamorphic belt", Southwest Japan. Memoirs of the Geological Society of Japan, 33, 343-357 (in Japanese with English abstract).

Norrell, G.T., Teixell, A. and Harper, G.D. (1989) Microstructure of serpentinite mylonites from the Josephine ophiolite and serpentinization in retrogressive shear zones, California. Geological Society of America Bulletin, 101, 673-682.

Nozaka, T. (2003) Compositional heterogeneity of olivine in thermally metamorphosed serpentinite from Southwest Japan. American Mineralogist, 88, 1377-1384.

Nozaka, T. (2005) Metamorphic history of serpentinite mylonites from the Happo ultramafic complex, central Japan. Journal of Metamorphic Geology, 23, 711-723.

Nozaka, T. and Shibata, T. (1995) Mineral paragenesis in thermally metamorphosed serpentinites, Ohsa-yama, Okayama Prefecture. Okayama University Earth Science Reports, 2, 1-11.

O'Hanley, D.S. (1996) Serpentinites: records of tectonic and petrological history. pp. 277, Oxford University Press, Oxford.

Ohara, Y. and Ishii, T (1998) Peridotites from the southern Mariana forearc: Heterogeneous fluid supply in mantle wedge. Island Arc, 7, 541-558.

Rinaudo, C., Gastaldi, D. and Belluso, E. (2003) Characterization of chrysotile, antigorite and lizardite by FT-Raman spectroscopy, Canadian Mineralogist, 41, 883-890.

Takahashi, E., Uto, K. and Schilling, J.G. (1987) Primary magma compositions and $\mathrm{Mg} / \mathrm{Fe}$ ratios of their mantle residues along Mid Atlantic Ridge $29^{\circ} \mathrm{N}$ to $73^{\circ} \mathrm{N}$. Technical Report of Institute for Study of the Earth's Interior, Okayama University, Series A, 9, 1-14.
Takeuchi, M., (2002) The Paleozoic. In Geology of the Shiroumadake district, quadrangle series, 1:50,000 (Nakano, S. et al. Eds.). pp. 105, Geological Survey of Japan, Tsukuba, 9-21 (in Japanese).

Toriumi, M. and Karato, S. (1978) Experimental studies on the recovery process of deformed olivines and the mechanical state of the upper mantle. Tectonophysics, 49, 79-95.

Trommsdorff, V. and Evans, B.W. (1972) Progressive metamorphism of antigorite schist in the Bergell tonalite aureole (Italy). American Journal of Science, 272, 423-437.

Trommsdorff, V. and Evans, B.W. (1974) Alpine metamorphism of peridotitic rocks. Schweizerische Mineralogische und Petrographische Mitteilungen, 54, 333-352.

Tsujimori, T., Nishina, K., Ishiwatari, A. and Itaya, T. (2000) 443403 Ma kyanite-bearing epidote amphibolite from the Fuko Pass metecumulate in the Oeyama area, the Inner Zone of southwestern Japan. Journal of the Geological Society of Japan, 106, 646-649 (in Japanese with English abstract).

Tsujimori, T. and Liou, J.G. (2004) Metamorphic evolution of kyanite-staurolite-bearing epidote-amphibolite from the Early Paleozoic Oeyama belt, SW Japan. Journal of Metamorphic Geology, 22, 301-313.

Uda, S. (1984) The contact metamorphism of the Oeyama ultrabasic mass and the genesis of the "cleavable olivine". Journal of the Geological Society of Japan, 90, 393-410.

Uemura, F., Sakamoto, T. and Yamada, N. (1979) Quadrangle series, 1:50,000; Geology of the Wakasa district. Geological Survey of Japan, Tsukuba.

Velinsky, V.V. and Pinus, G.V. (1969) Olivines with perfect cleavages in ultrabasites of Chukotok. Doklady of the Academy of Sciences of the U.S.S.R. Earth science sections (English translation edition), 185, 99-101.

Yamaguchi, K. (1990) Metamorphism of the Shitani Formation in the Sangun belt, Wakasa area, central Japan. Geological reports of Shimane University, 9, 29-36 (in Japanese).

Manuscript received April 8, 2010

Manuscript accepted July 15, 2010

Published online September 18, 2010

Manuscript handled by Akira Ishiwatari 